\title{
PENGUATAN KEDUDUKAN PRANATA HAK SERVITUT DAN HUKUM BERTETANGGA DALAM YURISPRUDENSI ${ }^{1}$
}

\author{
Oleh : Rizal Sofyan Gueci \\ Dosen Pascasarjana Magister Ilmu Hukum Universitas Pamulang \\ Email: rizal_gueci@yahoo.de
}

\begin{abstract}
Abstrak
Konstitusi telah meletakkan dasar check and balances antara organ negara utama eksekutif, legislatif dan yudikatif. Tatanan ini sebagai pedoman dalam bernegara dan bermasyarakat, bahkan sampai tingkat Desa/Kelurahan dan kelompok didalam seperti Rukun Tetangga dan Rukun Warga. Pranata Hak servitut dan hukum bertetangga dapat menjawab tantangan pembangunan permukiman dan perumahan yang berkelanjutan dan berketahanan. Hak servitut sebagai hak kebendaan yang diatur dalam hukum bertetangga dalam buku II BW (1848) tidak lebih tua dari hak melalui tanah orang lain yang dikenal oleh kesatuan masyarakat hukum adat hampir diseluruh wilayah Indonesia. Hak servitut adalah hak pengabdian pekarangan (erfdiensbaarheid) atau beban yang menindih pada pekarangan yang satu untuk kepentingan pekarangan yang lain sedemikian rupa sehingga pemilik pekarangan tertindih harus membiarkan pemilik pekarangan penindih untuk melintasinya, mengalirkan air (bersih) diatasnya, melepaskan pandang keluar lewat udara diatasnya dan sebagainya. Pengabdian ini tidak berakhir dengan meninggalnya atau bergantinya pemilik pekarangan yang bersangkutan (pasal $674 \mathrm{KUH}$ Perdata). Masih adanya sisa-sisa feodalisme dan kolonialisme pada masyarakat tribal, terlihat adanya kasus kasus kongkrit dalam masyarakat terdapat gangguan terhadap hak servitut dengan main hakim sendiri, maka negara hukum berulang-ulang dipanggil dan melahirkan yurisprudensi tetap. Kedudukannya hak servitut tidak tergoyahkan dengan adanya UUPA 1960 yang mengatakan semua hak atas tanah mempunyai fungsi sosial dan hukum adat dijadikan dasar dari hukum agraria nasional. Pasal Romawi I butir 6 UU No. 5 tahun 1960 membuktikan Indonesia berada dalam deretan negara negara beradab yang mengakomodir pranata hukum ini.Yurisprudensi telah mengangkat hukum adat sebagai living law sebagaimana juga SEMA 1963 memperlakukan BW sebagai hukum kebiasaan yang tidak tertulis demi mengisi kekosongan hukum dan tercapainya tujuan hukum. Yurisprudensi telah diakui sebagai salah satu sumber hukum yang sah di Republik Indonesia. Hakim Indonesia telah menunjukkan kelasnya dalam percaturan hakim dunia, yang tak ingin tampil beda dalam urusan hak servitut yang merupakan fenomena universal. Hampir semua negara negara beradab anggota PBB telah mengakui eksistensi pranata hak servitut ini, baik dalam Kitab Hukumnya maupun dalam yurisprudensinya. Pranata hak servitut ini berpangkal pada ius commune hukum kebiasaan sejak jaman Romawi, yang tidak dapat diabaikan, walau secara umum
\end{abstract}

${ }^{1}$ Naskah diterima tanggal 14 Juni 2016, direvisi: 28 Juni 2016, disetujui untuk terbit 1 Juli 2016 dalam Volume 3 No.1 Juli 2016 
hukum romawi bersifat individualistis, tapi secara khusus ada elemen fungsi sosialnya. Lembaga hukum servitut (lat.) ini diakomodir kedalam kitab kitab hukum negara negara di dunia , melalui penjajahaan , impor hukum, transplantasi sukarela dalam hukum awak. Boedi Harsono, sebagai pemikir nasionalis dan sosialis dan R. Soepomo tokoh hukum adat dan oleh pemuda 1928 dianggap sebagai hukum nasional dengan halus menyebutnya "hak melalui tanah orang lain" yang juga dikenal oleh hukum adat. Yurisprudensi tetap memperkokoh norma tidak tertulis hak servitut atau hak melalui tanah orang lain menunjukkan kelas hakim agung Indonesia setara hakim agung bangsa bangsa maju dalam menilai hak servitut ini. Kongkretisasi dalam membangun tanpa menggusur telah dipositifkan dalam UU No. 4 th 1992 ps. 22 - 32 dan UU 1 th 2011 tentang Permahan dan Kawasan Permukiman ps. 106 - 113 pranata konsolidasi tanah, yang kompatible dengan pranata hak servitut dan mengukuhkannya. Implementasinya, kalau satu developer saja sanggup membuat kaveling dan pematangan tanah hingga tertata hingga 6000 ha, satu provinsi atau satu pemkot/pemkab ditantang untuk mampu mengadakan konsolidasi tanah hingga 6000 ha untuk mengurangi backlog dan memberantas spekulan tanah. Untuk penilaian prestasi Gubernur/Kanwil BPN berapa sudah panjang jalan khusus, jalan umum atau jalan hak servitut melalui konsolidasi tanah dan berapa banyak jalan khusus yang sudah diserahkan jadi jalan umum.

Kata Kunci: Penguatan, kedudukan pranata, hak servitut

\begin{abstract}
The Constitution has laid the foundation of checks and balances amongst the main state organs namely the executive, the legislative and the judicial power. This order as a guideline in the state and society, till the Village level and within groups in the village such as the Neighborhood and citizen groups. Servitut Rights and neighbors law answer challenges of development of human settlements sustainably and resilient. Servitut rights as a property rights regulated in Neighbor law book II Indonsian Civil Code of 1848 or in adat law term called easement (hak melalui tanah orang lain) which known by adat community entity is not older than the easement is recognized by customary law in almost adat law community entity throughout the territory of Indonesia. The servitut right is the easement of yard (erfdiensbaarheid) or burden to rest on the grounds that one for the benefit of the another yard such that the owner of the yard were crushed should let the owner of the yard oppressor to pass through, drain the water (clear) on it, take view out through the window etc. This devotion land does not end with the death or replacement of yard owners concerned (Article 674 of the Indon. Civil Code). There are still remnants of feudalism and colonialism in tribal society, reflecting the concrete cases in the community there is disturbance against the rights of servitut with vigilante, then the rule of law invoked repeatedly and generating permanent jurisprudence. Kedudukannya hak servitut tidak tergoyahkan dengan adanya UUPA 1960 yang mengatakan semua hak atas tanah mempunyai fungsi sosial dan hukum adat dijadikan dasar dari hukum agraria nasional. The position of Servitut rights is impregnable with the Basic Agrarian Law 1960 (BAL) that says all rights on land has social functions and customary law form the basis of the national agrarian law. In Article I point 6 of BAL No. 5 year 1960 proves Indonesia is in a row of civilized countries that accommodates this legal institution. Jurisprudence confirm customary
\end{abstract}


law as a living law as well as the Civil Code 1848 according to Supreme Court Circuler of 1963 treat as unwritten customary law in order to prevent the legal vacuum and reaching the objectives of the law. Jurisprudence has been recognized as one of the legitimate source of law in the Republic of Indonesia. Indonesian Judges have shown its class in the world of justice, who did not want to look different in servitut rights issues which is an universal phenomenon. Almost all civilized countries of the UN members have recognized the existence of this institute servitut rights, both in the Code book as well as in its jurisprudence. Servitut rights institution is rooted in the common law ius commune since Roman Empire, which can not be ignored, despite overall individualistic Roman law, but in particular there are elements of social function. Servitut (lat.) is accommodated into the book of the law in almost all countries in the world, through colonialize, import law, voluntary transplants in the law of one self. Boedi Harsono, as nationalist and socialist thinker and R. Supomo as father of Indonesian customary law and by youth in 1928 is regarded as a national law with the smooth call it "right through another person's land" which is also known by the common law. The permanent Jurisprudence remains threngthen unwritten norm servitut rights or land rights through anothers person's land showed the class of Indonesian Judges comparabele with justices of developed nations in assessing this servitut rights. Implementation build without displacing has been regulated in Law No. 4 year 1992 art. 22-32 and Act No. 1 year 2011 on Housing and Settlement Region art. 106113 law institute land consolidation, which is compatible with the institute servitut right and reconfirmed the servitut. Implementation, if one developer alone could make the plot and make the land ready to build cosolidate up to 6,000 ha orderly development of land, so a province or a local government / city are challenged to be able to hold up to 6,000 ha of land consolidation to reduce the backlog and combating land speculators. For the assessment of achievement of the Governor / Regional Office of $B P N$ how long had a special local street, public street or road of servitut rights through land consolidation and how many special streets that have been submitted become public streets.

Keywords: Reinforcement, top notch institutions, rights servituut

\section{A. Pendahuluan}

Setiap tanggal 17 Agustus dimana kita merayakan hari kemerdekaan Republik Indonesia, dan dengan tulisan ini diundang pembaca sejenak kilas balik kedunia lain dan mengheningkan cipta, apakah kaum marginal kita sudah menikmati kemerdekaan itu? Apakah prinsip kesetaraan yang jadi semboyan revolusi Perancis 1789 dan dalam UU 1 th 2011 ps 112 ay 2 sudah diimplementasikan? Untuk itu dibayangkan pembaca berjalan jalan sejenak ke New York dan Hong Kong. New York semula bernama New Amsterdam, ibu kota dari New Netherland, yang merupakan koloni dari Dutch West Indie Coy, didirikan tahun 1624. 
Akan tetapi karena persaingannya dengan Inggeris tahun 1664 Belanda terpaksa menyerahkannya kepada Inggeris dbp Richard Nicolls dan Nicolls mengganti namanya menjadi New York hingga sekarang, yang berlokasi di Manhattan, diatas pulau Manahatta. Sebagai imbalannya Belanda mendapatkan dari Inggeris wilayah pulau Run, Kep. Banda Neira, bagian Propinsi Maluku sekarang, yang sudah dijadikan koloni Inggeris sejak 1621 diserahkan kepada Belanda 3 tahun kemudian dengan perjanjian Breda $1667^{2}$.

Penulis beruntung melihat langsung New York dan menyaksikan bahwa penduduk asli Belanda dan Jerman di bagian bagian kota New York masih ada dan tidak tergusur oleh penguasa/Inggeris atau USA 1774 pasca kemerdekaannya. Bagaimana best practice USA membangun tanpa menggusur? Kemudian dibayangkan kita pergi ke Hong Kong. Walau Inggeris memenangi Perang Candu 1839-1842 dengan Perjanjian Nanking 1842 Cina harus menyerahkan Hong Kong kepada Inggeris , namun Cina terus menekan agar Inggeris menyewa Hong Kong kepada Cina dan Cina berhasil dengan Konvensi Peking Juni 1898 untuk selama 99 tahun. Sejak 1980 Inggeris melobi Cina untuk memperpanjang sewanya tapi Cina keras kepala, Inggeris gagal dan tanggal 30.6.1997 sewa menyewa Hong Kong berakhir dan Inggeris harus mengembalikan Hong Kong kepada Cina, setelah menjadi koloni (tinggal mengelompok) Inggeris selama 155 tahun $^{3}$.

Apakah penduduk asli Hong Kong tergusur akibat pembangunan? Venuenya diganti di Indonesia, apakah di kota kota akibat pembangunan penduduk aslinya tergusur? Bila ya maka program pemerintah membangun tanpa menggusur sudah terlambat. Tidak ada kata terlambat, lebih baik terlambat daripada tidak ada sama sekali. SEMA 1963 meletakkan BW mempunyai kekuatan sebagai hukum kebiasaan tidak tertulis, kecuali sepanjang secara tegas lembaganya dicabut. Hukum adat seiring berjalannya waktu melemah, untung dikawal oleh yurisprudensi tetap dan telah mengakui lembaga servitut ini ${ }^{4}$.

\footnotetext{
${ }^{2}$ Widiati, Sri, Banda Naira: Pulau Rempah yang menyimpan sejarah besar. Dalam Majalah Garuda Edisi Juni 2008 Jakarta h. 116 - 118, lihat juga Doonukuneke.wordpress.com, Barter Pulau Run, Maluku engan Manhattan. diakses tanggal 17.07.2016

${ }^{3}$ Asep Setiawan.worpress.com, Hong Kong transisi Cina ke Inggeris, diakes 17.7.2016

${ }^{4}$ Sumber Pengertian Hak Servitut, Lihat juga Subekti, Kamus Hukum, cet. 3 th. 1979 hal. 5
} 


\section{B. Rumusan Masalah}

Dalam tulisan ini diangkat permasalahan sebagai berikut :

1. Mengapa hak servitut kedudukannya tidak tergoyahkan dalam yurisprudensi tetap Indonesia?

2. Bagaimana kongretisasi evaluasi komitmen program Pemerintah membangun tanpa menggusur?

3. Bagaimana persiapan konsolitasi tanah yang benar ?

Dalam mendekati masalah ini digunakan kajian pustaka dan metode empiris, yaitu pengalaman dan pengamatan sendiri (participant observation) di Serpong, Tangerang.

\section{Pembahasan}

\section{Kebutuhan Akan Rumah}

Kebutuhan akan hak servitut dan hukum bertetangga berbanding lurus dengan dibangunnya perumahan dan permukiman, yaitu rumah tunggal, rumah susun dan rumah deret. Dalam permukiman ini terdapat rukun tetangga dan rukun warga, artinya sesama tetangga seharusnya rukun dan sesama warga seharunya punya kesadaran kewargaan (polis). Masyarakat punya penyakit lupa, dibanyak permukiman banyak kearifan lokal , kebiasaan dan adat istiadat dan nilai nilai baik tidak diketahui lagi oleh generasi berikutnya. Disinilah hukum bisa mengisi kekurangan tersebut dengan mengangkatnnya dalam tatatan yurisprudensi dan mensosialisasikan kearifan kearifan lokal yang punya nilai filosofis yang tinggi kedalam tatanan pragmatis sosiologis. Bila dalam menyusun norma itu tiga aspek tersebut yuridis, filosifis dan sosiologis diperhatikan, maka norma hukum itu akan mudah dipahami oleh masyarakat dan dipatuhi oleh masyarakat dan belaku dalam waktu yang cukup panjang, bahkan tahan uji terhadap waktu dan tempat, ibaratkan hukum adat, sebagai hukum yang hidup.

Seiring dengan naiknya daya beli masyarakat maka kebutuhan akan rumah meningkat. Infrastruktur lunak seperti aturan telah disiapkan, seperti UU No. 26 th 2007 tentang Penataan Ruang, UU Perumahan dan Kawasan Permukiman No. 1 th 2011 yang menggantikan UU No. 4 th 1992. Sangat disayangkan Pemerintah menyerahkan tanah untuk perumahan ini kepada masyarakat, sehingga distribusi tanah tidak merata dan mengakibatkan tingginya harga tanah. Kalau pemerintah dengan BLU, BUMD atau 
BUMNnya ikut melakukan pengadaan tanah, pematangan tanah menjadi kasiba, aktiv dan proaktiv menggunakan pranata konsolidasi tanah, maka harga tanah tidak akan meroket seperti sekarang ini, sehingga direkayasa pengertian satu hamparan asal satu kota/kabupaten memenuhi syarat. Bila pemerintah aktiv sebagai pelaku pematangan tanah menjadi kasiba, maka inovasi inovasi produk dan lesson learned and best practice dari tempat lain, dapat dikembangkan.

Kalau diserahkan pada masyarakat developer semua, maka mereka bisa dapat keuntungan yang sebanyak banyaknya. Sehingga cenderung monoton satu produk, yaitu cluster, padahal rumah cluster tidak berkelanjutan dan berketahanan, karena berangkat dari ketakutan dan bukan dari kewargaan (polis), sehingga benteng benteng ini mengunci dirinya sendiri (gated communities), set back kepada jaman kompeni VOC atau pengelompokan berdasarkan ras dan golongan penduduk pada jaman Belanda (pemukiman orang Eropa, pemukiman Cina, pemukiman pribumi Kampung Jawa, Kampung Bugis dlsb) ${ }^{5}$.

Pada hal dikenal pola lain seperti pola rumah ganda, town house, satu rumah induk tiga rumah terjangkau dalam satu kawasan yang sebenarnya, pola cohousing (Skandinavia, USA), dimana pola dua terakhir ini cocok menurut hemat penulis cocok untuk Indonesia, karena penghuninya saling bekerjasama dan hidup suasana rukun. Life style ini pernah ada di daerah Kramat, Jakarta pada tahun 1920 an dimana satu rumah Induk ada dua rumah terjangkau dibelakangnya untuk tukang kebun atau tukang masak dan satu lagi disamping untuk baby sitternya (1:3). Ini untuk rumah kalangan menengah waktu itu, seperti untuk Kepala Kantor, Akademisi dan Profesional. Untuk kalangan atas biasanya orang Belanda mempunyai 6 pembantu, jadi ada 6 rumah satelit dalam satu kehidupan komunitas tempat tinggal. Konsep konsep ini menginspirasi kebijakan 1:3:6 dalam satu hamparan (dalam arti sebenarnya) Era Ordebaru6 .

Apabila mereka tidak mau tinggal dekat rumah Induk atau Aristokrat maka satu hamparan diartikan satu RT atau RW atau kampung, paling jauh dalam satu desa, sehingga kerjasama fungsional dapat berjalan dengan baik. Dalam Era Reformasi, Era

\footnotetext{
${ }^{5}$ Kembali ke domain tiga kelas warga ISR Stsbl 1854 : 2 ps 131 jo ps. 163

${ }^{6}$ Ginanjar Kartasasmita, Kebijakan Penataan Ruang Nasional dalam menggarahkan Pembangunan Perumahan dan Permukiman yang bertumpu pada Pemberdayaan Masyarakat, dalam Seminar Nasional Perumahan dan Permukiman Menyongsong Abad 21, Jakarta 27.19.1997
} 
Jokowi kebijakan kontraproduktif terhadap backlog, dengan mengunggulkan sistim $1: 2: 3^{7}$. Diperparah dengan naiknya harga tanah, untuk rumah terjangkau jauh dari tempat kerja mereka, sehinga menimbulkan masalah baru bagi MBR. Apalagi bantuan dari negara donor dengan pinjaman lunak hasil infrastruktur summit dan masuknya dana dana orang Indonesia yang diparkir di luar negeri, akan menambah pembangunan infrastruktur termasuk didalamnya perumahan vertikal dan horizontal. Kebijakan menteri sistim 1:2:3 , 3 untuk rumah terjangkau akan memperlama pengurangan backlog atas perumahan.

\section{Rencana Detail Tata Ruang dan Desain Konsoliasi}

Keadaan tahun 1971 seorang Boedi Harsono masih yakin bahwa hukum adat yang meletakkan dasar bahwa hak atas tanah mempunyai fungsi sosial dan yakin ketentuan ketentuan hukum adat itu tetap merupakan hukum yang hidup dan tahan uji terhadap waktu dan tempat, ternyata meleset, dengan intervensi rezim UU Desa tahun 1979 dan masuknya Era Internet tahun 1990, membuat dunia dan masyarakat berubah, pengaruh global community dan global society semakin derasnya , dimana masyarakat mencontoh yang jeleknya lebih mudah daripada mencontoh yang baiknya, sehingga kesatuan masyarakat adat terancam, sudah banyak lupa substansi hukum adatnya, sesuatu yang tidak terpikirkan oleh generasi generasi sebelumnya. Untunglah sebagian telah diakomodir oleh yurisprudensi Indonesia, dan bertahan tetap merupakan hukum yang hidup (the living law) dan mempertegas pengakuan negara terhadap kesatuan masyarakata hukum adat (ps 18 B ay 2 UUD) yang didalamnya sudah integrated hukum adat.

Hukum adat mengenal semacam hak servitut, yang disebutnya "hak melalui tanah orang lain”. Dengan sendirinya UUPA ada memuat konsolidasi tanah. Objek konsolidasi adalah tanah dalam pembuatan jalan umum atau jalan khusus. Jalan hak servitut termasuk jalan khusus, tapi tidak mustahil meningkat ke jalan umum, apabila syarat syarat teknisnya terpenuhi. Dalam konsolidasi tanah dibuat kaveling-kaveling dan dengan kesepakatan bersama, misalnya direlakan $20 \%$ atau $10 \%$ (menurut kesepakatan bersama) agar tanah optimal penggunaanya, walau terkena proyek jalan

\footnotetext{
${ }^{7}$ Wawancara dengan Alberto Padova, Kepala UN Habitat N.Y di NY (padova@un.org) a.n. LSM YUPI, 2014
} 
(fungsi sosial hak atas tanah). Warga tidak keberatan pengembalian tanahnya lebih kecil asal semua tetangga dapat akses jalan umum dan jalan khusus dan tertata dengan baik. Bentuknya bisa kesepakatan tanah sumbangan 20 \% misalnya, $10 \%$ dengan ganti rugi/untung, 10 \% lagi sumbangan sukarela. Yang penting dalam pelaksanaannya tidak ada titipan dan KKN. Jalan umum sebagai peningkatan pelayanan pemerintah kepada masyarakat dapat melalui pengadaan tanah untuk kepentingan umum, a. melalui jalur pembebasan tanah dengan ganti rugi; b. melalui jalur konsolidasi tanah; c. jalur kombinasi, konsolidasi dan ganti rugi.Prinsip konsolidasi adalah penataan pertanahan dalam rangka mengakomodasi kegiatan kegiatan pembangunan baik di perkotaan maupun pertanian/pedesaan yang menuntut terwujudnya suatu bidang/persil tanah yang tertib dan teratur sesuai dengan Rencana Tata Ruang. Tujuannya mencapai pemanfaatan tanah secara optimal, melalui peningkatan efisiensi dan produktivitas peningkatan $\operatorname{tanah}^{8}$.

Selaku anggota PBB pemerintah tidak boleh pasiv dengan cara menyerahkan kepada swasta untuk membuat kasiba dan pematangan tanah, dan dengan demikian target pembangunan rumah sederhana sulit tercapai dan program Nasional "KOTAKU” ${ }^{9}$ sulit diatasi, karena swasta membiarkan kumuh agar mudah dicaplok. Periksa saja pekarangan pekarangan dibalik tembok berlin, kumuh dan tidak sehat. Pemerintah terlalu berani membuat hutang luar negeri dari AIIB (Cina), World Bank, ISDB dan Pemerintah Australia. Kenyataan fasilitas ini juga akan mengalir untuk KPR rumah menengah dan atas, hasil lobi lobi mengubah konsep berimbang 1:2:3 atas kerugian MBR dan perubahan pengertian satu hamparan dari satu Kampung atau satu Kelurahan menjadi satu kota/kabupaten.

Apabila diserahkan segalanya kepada swasta , swasta mempunyai banyak kepentingan, apalagi bila diberikan ijin lokasi seluas 2000 ha, maka tidak jarang akan jadi bumerang bagi pemda yang membagi bagikan ijin lokasi tadi, karena dapat dikooptasi oleh swasta besar tersebut. Untuk itu bagi badan hukum yang telah pernah dibagi tidak diberikan tambahan lagi, karena dalam keadaan sekarang untuk membebaskan tanah 2 ha, 200 ha saja sudah sulit dan mahal, apalagi 2000 ha. Eksesnya banyak, walau ijin lokasi itu bersyarat misalnya wajib menghormati semua hak atau

\footnotetext{
${ }^{8}$ Lihat Peraturan BPN 1991 No. 4 jo Surat Kep. BPN 410 - 4245 tanggal 7.12.1991

${ }^{9}$ Singkatan dari Kota Kumuh
} 
kepentingan pihak lain yang sudah ada atas tanah yang belum/tidak bersedia melepaskan hak atas tanahnya, maka developer dilarang menutup atau mengurangi aksesibilitas yang dimiliki masyarakat disekitar lokasi, demi menjaga dan melindungi kepentingan umum, dalam pelaksanaan pengawasnya tidak ada bahkan mendiamkan ${ }^{10}$.

Rumah ada nilai filosofisnya, my home is my castle, small but mine. Keadaan rukun, damai itu indah tidak hanya slogan, tapi bagaimana negara menyikapi memupuk rasa kewargaan (polis) dan kesetaraan. Justru dalam memperingati 17 Agustus, sikap kesetaraan harus menggeser sikap exclusivisme , a la perumahan di Era kolonial, yaitu satu rumah induk, tiga rumah terjangkau (untuk tukang kebun, tukang masak dan tukang rawat anak $)^{11}$. Sehingga disinyalir konsep terakhir ini (1:2:3) tidak berkelanjutan dan tidak berketahanan, melanggar motto egaliter dan kewargaan yang dicanangkan oleh revolusi Perancis ${ }^{12}$ dan bergema juga pada awal 20 di Nederland Indie, yang membakar semangat oleh para perintis kemerdekaan kita untuk berjuang menyusun strategi untuk bebas dari penjajahan dan mencapai kemerdekaan.

Pendiri negara telah sepakat mengambil asas kekeluargaan sebagai turunan dari sila ke 5 dari Pancasila yang dimuat dalam Pembukaan UUD dan pasca amandemen asas kekeluargaan dipertahankan, walau dipasangkan dengan efisiensi berkeadilan, tetapi dari segi urutannya asas kekeluargaan duluan diatur ay (1) dan karenanya mempunyai fungsi dan kedudukan lebih penting ketimbang efisiensi yang diatur belakangan ayat (4) dalam pasal 33 UUD, sehingga bila penerapannya bertentangan maka ayat 1 yang diutamakan jalan lebih dulu.

Dalam mengurai asas kekeluargaan ini dipakai grand theory dari Otto von Gierke, John Rawls dan Amitai Etzioni mengenai masyarakat organis, keadilan sosial dan communitarian society atau masyarakat plural. Untuk middle range theory didasarkan pada pendapat pada teori HAM Maurice Cranston dan Karel Vasak. Cranston argued that scarcitymeans that supposed second-generation and third-

${ }^{10}$ Kasus Kisin Miih qq Rachmiati ASL vs. PT Smart Telecom dan PT BSD, Tbk No. 191/Pdt.G/2009 jo Putusan Pengadilan Tinggi No. 246/Pdt/2011 jo MA RI No. 3409/K/Pdt/2012 diputus tanggal 27 Agustus 2014, yang membenarkan hak servitut warga, karena orang tua mereka telah dengan sukarela menyumbangkan haknya untuk kepentingan umum dan keindahan lingkungan, karenanya harus dilindungi oleh UU, jalan mana telah ditingkatkan jadi jalan umum, terus agar dapat dijual diturunkan jadi jalan khusus (lingkungan), tapi kenyataannya warga penduduk asli jalannya ditutup dengan tembok berlin, akhirnya dengan putusan MA harus dibuka kembali tembok berlin tersebut.

${ }^{11}$ Lihat H.B. Jasin, terjemahan dari buku Belanda Johanes Theodorus Boon/Vincent Mahieu, Tjies dan Tjoek, 1976 orig.

${ }^{12}$ Vasak, Karel, Human Rights, A Third Year Struggle ... , Unesco 1977 
generation rights are not really rights at all. If one person has a right, others have a duty to respect that right, but governments lack the resources necessary to fulfill the duties implied by citizens' supposed second- and third-generation rights ${ }^{13}$. Vasak sebagai pengawal visi dari Revolusi Perancis Liberty, Equality, Fraternity. Jembatan antara dari generasi kedua dan ketiga right to economic and social development rigt to development dan sebagai applied theory diambil dari R Supomo tentang teori integrasi dan asas kekeluargaan dan pertimbangan UU Jalan No. 38 tahun 2004. Disini sudah sepatutnya jalan khusus tertentu diusahakan menjadi bagian jalan umum untuk lebih meningkatkan pelayanan Pemda kepada masyarakat, terutama masyarakat yang belum tersentuh pembangunan dan menjadi korban langsung dari pembangunan. Jalan sebagai salah satu prasarana transportasi merupakan unsur unsur penting dalam pengembangan kehidupan berbangsa dan bernegara dalam pembinaan persatuan dan kesatuan bangsa, wilayah negara dan fungsi masyarakat serta memajukan kesejahteraan umum. Jalan mendukung bidang ekonomi, sosial dan budaya serta lingkungan (generasi ketiga HAM) agar tercapai keseimbangan pemerataan pembangunan antar daerah, mewujudkan sasaran pembangunan nasional diperlukan keterlibatan masyarakat.

Masalahnya banyaknya pengembang ingin membangun dalam daerah yang padat penduduk ketimbang daerah baru, lebih untung membangun dengan menggusur, ketimbang membangun tanpa menggusur . Untuk itu peran hak servitut dan sosialisasi hukum bertetangga akan semakin pentingnya dan untuk itu pemerintah dengan setengah hati meluncurkan lembaga konsolitasi tanah dalam lalu lintas hukum di Indonesia dan dipertegas dalam UU Perumahan dan Permukiman yang baru.

Menurut Boedi Harsono hak ini dapat dikonversi untuk menjadi HGB (bila bakal dibangun) dan hak pakai bila tetap fungsinya jalan khusus atau jalan umum. Bila tidak ada aturan konversi hak ini tetap berlaku, karena BW sebagai hukum kebiasaan tidak tertulis , telah disinkronkan dengan hukum adat, dan hukum adat telah mengakui dan telah mengatur lembaga hukum berupa "hak melalui tanah orang lain” yang bertetangga (mirip hak servitut ) ${ }^{14}$. Lebih lanjut Boedi Harsono membenarkan Soepomo dan memastikan dalam Hukum Adat sudah ada ketentuan ketentuannya mengenai hak

${ }^{13}$ Cranston, Maurice. "Human Rights: Real and Supposed," dalam Political Theory and the Rights of Man, edited by D. D. Raphael (Bloomington: Indiana University Press, 1967), pp. 43-51

${ }^{14}$ Lih. Boedi Harsono, cat pinggir no 327 hal 384, cp 291 h. 337, Jakarta 1971 dan R. Soepomo 1982 hal. 105 
guna air dan hak servitut tersebut. Karenanya itu pulalah yurisprudensi tetap telah mengakui dan mengukuhkan hak servitut tersebut. Untuk itu persiapan konsolidasi tanah harus benar, tertib dan adil, tidak ada titipan atau KKN pesan sponsor.

\section{Cluster Perumahan vs Co-housing}

Semisal Cohousing dari USA Charles Durrett, yang mirip rumah bangunan jaman Belanda di daerah Kramat, Jakarta Pusat yaitu satu rumah induk diapit dengan 3 rumah sederhana sebagai satu kesatuan (satu hamparan dalam arti yang sebenarnya), mendukung satu rumah induk. Perumahan ini berbeda dengan konsep cluster (gated communities) dimana ekonomi penghuni satu level dalam satu hamparan.

Developer dalam membebaskan tanah sudah merupakan rahasia umum, suka mendompleng program pemerintah. Misalnya pemerintah melakukan pengadaan tanah untuk jalur gas, developer nitip pada BUMN terkait, agar beli murah dengan jual mahal. Momen pembebasan jalur jalan, jalur gas , jalur tegangan tinggi, seringkali dimanfaatkan oleh developer untuk ikut belanja pengadaan tanah, dengan mencatut kepentingan umum, yang mengorbankan rakyat dengan tembok tembok berlinnya. (berlin wall, Berlin Mauer).

Belajar dari kasus korupsi dalam Rapperda Reklamasi yang melibatkan developer besar maka sudah waktunya pemerintah dan KPK membuka post box pengaduan masyarakat agar developer besar lainnya terbongkar pelanggarannya dalam memperoleh tanah, pemerintah tidak boleh berhenti dari kasus developer AS . Konsolidasi tanah di pemukiman padat, jarang terdengar. Di Pemukiman sedang dan lengang juga tidak berjalan. Patut diduga telah memberikan peluang kepada administrator lurah dan camat ikut jadi calo tanah dan supaya developer dapat membebaskan tanah dengan harga murah, dengan alasan tidak ada jalan atau sertipikat.

Penyebab penggeseran dan penggusuran industri semen berkontribusi dengan inovasinya mulai mengembangkan barbagai macam produknya. Semula pagar proyek yang terbuat dari pagar seng telah diganti dengan pagar duracon, untuk intimidasi memudahkan pembebasan tanah, menyulitkan atau menakut nakuti warga agar tanahnya dijual dengan harga murah. Selesai proyek fasos fasum yang dibangun tidak langsung diserahkan pada pemda dengan alasan pintar pintarnya mereka. Industri semen dan developer berjaya tapi dilain pihak merupakan horor bagi penduduk, terutama yang 
rumahnya menjadi korban dipagar berlin. Ditempat asalnya memisahkan komunis dan kapitalis, disini memisahkan masyarakat the have dan the have not. Tembok berlin sering kali merupakan ancaman jalan (umum dan khusus) warga, sewaktu waktu akan ditutup dan konsekuensinya harga tanah mereka jadi jatuh, dengan alasan tidak ada jalan. Tahap berikutnya wilayah mereka menjadi daerah kumuh dan sarang nyamuk dan banyak penyakit karena angin dan sirkulasi udara terhambat dan pandangan dari jendela rumah rakyat tertutup. Hal ini harus ditelan oleh rakyat mengalah, demi pembangunan, tapi sampai kapan? Pentingnya konsolidasi tanah agar peningkatan pelayanan masyarakat, dimana mobil ambulan dan mobil pemadam kebakaran, truk sampah dapat tanpa hambatan menuju lokasi yang diperlukan.

Sejalan dengan diperlonggarnya bisnis outsourcing (UU 13 th 2003), maka bisnis keamanan merupakan bisnis kompatible dengan pengembang, yang berkaitan langsung atau tidak langsung dengan bisnis pengembang. Standar pelayanan keamanan cukup dilakukan oleh polisi atau perlu tambahan dengan pam swakarsa atau satpam, tergantung kepada apakah developer ingin mendapat margin uang IPL dari penghuni rumah yang telah dijualnya.

\section{Damai itu Indah, belajar dari anak anak.}

Tulisan ini merupakan campuran kajian normatif dan hasil pengamatan dan pengalaman penulis (partisipant observation) dan penulis mencoba menguraikan hasil yang bertujuan untuk memecahkan masalah yang diangkat. Tidak mustahil keadaan ini dapat juga dialami oleh masyarakat lain dan solusi ini dapat ditawarkan untuk mencegah timbulnya persoalan baru, selagi penduduknya belum sepadat Tangerang dan konsolidasi tanah segera turun untuk mengatur jalan khusus atau hak servitut untuk menjadi jalan umum, yang kondisi daerah dan persoalannya hampir sama/mirip.

Tema kecil tulisan ini terinspirasi bagaimana orang dewasa bisa belajar dari anak anak, tidak peduli apakah dari anak anak kampung atau anak anak yang tinggal kota/kompleks perumahan . Karena anak anak dalam keseharianya dalam bermain dan anak anak lain, tidak pandang ras dan tidak pilih teman berdasarkan kekayaan, tempat tinggalnya, bentuk rambut, bentuk mata dan hidung, karena orang dewasalah yang ada beban tersebut. Anak anak selalu ceria dan bermain satu sama lain kesana kemari bercanda ria sesama teman, dan hidup damai dengan tetangganya tanpa punya 
prasangka negativ satu sama lain. Tidak terlihat rasa kecanggungan diantara mereka, bila ada gesekan gesekan, dengan hitungan jam dan hari mereka kembali berbaikan dan bermain bersama lagi.

Persoalan yang sengaja ditiupkan oleh developer dan pebisnis security bagaimana meningkatkan kebutuhan akan rasa aman antara warga pemukiman dan warga kompleks, akan tetapi mereka lebih fokus kepada warga kompleks karena daya belinya lebih kuat, walaupun kebutuhan akan rasa keamanan tidak berbeda bagi orang yang tinggal di kampung dan kompleks. Banyak orang merasa rasa keamanan dan perlindungan dari rasa ketakutan ini hanya milik eksklusiv warga kompleks perumahan. mereka sebagai orang kaya yang tinggal di kompleks, yang satu kompleks terbuka (inklusif) yang satu lagi pasca krismon mulai muncul kompleks yang berbenteng (gated communities) atau diperhalus oleh developer sebagai cluster, meminjam istilah atau citra pada cluster pada sektor industri. Tetapi mereka lupa bahwa warga kampung (permukiman penduduk) juga butuh akan rasa aman ini dan akan tetapi keamanan sesuatu yang luxus buat mereka, walau keamanan adalah tugas pemerintah, tapi PNS mengurangi tugasnya sekalian berbisnis, karena ada Iuran Pengelolaan Lingkungan (IPL) untuk keamanan sehingga tidak ada warga perumahan yang peduli dan kritis bertanya kenapa mereka di isolir , kenapa mereka tidak berhak memperoleh akses jalan, keamanan dan fasos fasum - dengan adanya tembok berlin yang kokoh dan masiv yang menutup jalan-jalan dan permukiman mereka dan pagar pagar BRC yang membatasi satu RT dengan RT lainnya.

Dengan berkunjung ke TMP pada hari Kemerdekaan 17 Agustus, diresapi jujur kemerdekaan buat siapa, apakah keadaan ini sesuai dengan cita cita kemerdekaan yang diperjuangkan para syuhada tersebut. Apakah kaum marjinal sudah memperoleh kemerdekaan tersebut, jalan sebagai wujud kebebasan bergerak (pasal 28 E ay 1 UUD), tapi hak akses jalannya dirampas oleh tetangganya dengan meminta developer menutupnya pakai tembok berlin. Sekarang pendatang yang tinggal di kompleks merasa content dengan life style hidup eksklusiv yang ditiup tiupkan oleh swasta dan didiamkan oleh pemerintah dan sudah barang tentu hal ini akan merugikan hak-hak dan kepentingan kaum yang lemah, sehingga muncul stereotype-stereotype baru, prasangkaprasangka sosial baru, seperti ada kampung maling, cluster koruptor atau penyelundup yang bersembunyi dalam cangkangnya. Dari pengalaman dan pengamatan tersebut 
(kasus empiris $)^{15}$ tampaknya developer sengaja mempertajam perbedaan dan prasangka yang ada untuk keuntungan bisnisnya. Aturan Pemda DKI developer satu tahun setelah proyek selesai harus menyerahkan fasos fasumnya. Di Tangerang setelah tiga tahun. Tapi siapa yang peduli mengawasinya. Developer tentu punya kiat kiat untuk tidak segera menyerahkan fasos fasum, dengan alasan Pemda belum siap menerima penyerahan jalan khusus kepada pemkot. Walau proyek sudah selesai dan terjual mereka tetap ingin memperoleh margin dari IPL maka berkepentingan untuk menunda status jalan dari jalan khusus ke jalan umum didiamkan oleh Pemda. Karena itu perlu ada pengaturan dan kepastian. Menurut R. von Jhering pertentangan kepentingan dua kelompok lapisan menengah dan bawah akan memicu konflik, bila pemerintah tidak melindungi yang lemah. Artinya bila pemerintah bersifat membiarkan, maka artinya pemerintah telah berpihak kepada kepentingan golongan yang lebih kuat ${ }^{16}$. Sehingga keadaan masyarakat menjadi rentan, keadaan hukum yang kuat mengatur yang lemah (dominasi), membiarkan yang kuat menggunakan kemerdekaan dan kebebasannya dengan modal yang ada ditangannya dan dengan lobi lobi ke pejabat.

Dalam pemukiman cluster dan pemukiman kampung yang diamati penulis, tampaknya orang dewasa yang sudah enak posisinya tidak mau belajar dari anak anak mereka. Sulit untuk melepaskan kenikmatan exklusivitas, sehingga tampaknya orang dewasa tidak /belum dapat mengambil hikmah belajar dari keteladanan anak anak untuk menciptakan persatuan dan kesatuan masyarakat yang beradab, suatu civil society dimana anak anak mereka bermain bersama tanpa beban, tanpa melihat warga kulit dan bentuk matanya.

\section{Tembok Berlin}

Apakah negara harus membiarkan dua pertarungan dua golongan yang tidak seimbang yang terjadi dalam masyarakat? Dunia semakin kecil dan penduduk bertambah padat dan muncul pola hidup masyarakat global yang merealisasikan hidup guyub dalam komunitas rumah bersama ${ }^{17}$.

Supomo dan Amitai Etzioni telah melihat pola masyarakat plural ini, seperti kehidupan dalam suatu kesatuan masyarakat hukum adat, yang organis dan fungsional

\footnotetext{
${ }^{15}$ Lihat Kisin Miih cs vs. Smart Telecom dan BSD.

${ }^{16}$ Rudolf von Jhering, Law as Means to and End

${ }^{17}$ Vision Murundaka Global Community, Australia
} 
dan dengan bantuan internet lebih mudah dan relatif cepat menemukan orang orang yang satu visi dan misi untuk membentuk komunitas global berkat jasa IT media sosial dan internet ${ }^{18}$.

Bencana alam, kerusuhan sosial, penyakit menular yang menimpa dunia sana, bisa dalam sekejab dapat melanda dunia sini , sehingga semua ini harus diatasi bersama, secara terintegrasi, tidak parsial. Pemerintah dituntut perannya selaku mediator dan fasilitator dalam menghadapi dua golongan yang kepentingannya berseberangan satu sama lain, dengan arif dan bijaksana dalam membuat suatu keputusan yang adil dan diikuti secara sukarela oleh kedua golongan yang bersaing tersebut. Pemerintah mendorong proses interaksi sosial dalam berbagai lapisan sosial masyarakat berjalan lancar tanpa mempertajam kelas kelas yang ada dan tanpa halangan halangan secara fisik (tembok berlin dan pagar pagar tembok yang tinggi).

Bagaimana prasangka orang dewasa dapat dihapuskan dari belajar pada keteladanan anak anak? Keadilan akan terhadap Infrastruktur jalan dapat mendorong kedamaian dan kerukunan antar hidup orang bertetangga dalam rangka melaksanakan pembangunan yang berkelanjutan. Sesama warga baik yang tinggal di permukiman maupun perumahan harus merasa terpanggil membuat jembatan atau jalan sebagai ujud aksessibilitas masyarakat satu terhadap masyarakat lainnya sehingga dapat mendorong terjadinya kedamaian dan kerukunan antar bertetangga. Didirikannya balai warga bersama atau ruang publik bersama. Jalan khusus tidak selalu terus menerus didaulat oleh pengelola perumahan dan untuk mencegah diskriminasi secepatnya diserahkan kepada pemerintah, sehingga proses interaksi sosial , kesatuan dalam balai warga antara warga dapat berjalan lancar.

Bagaimana pemerintah harus lebih meningkatkan pelayanan umum kepada masyarakat tanpa pandang bulu, tanpa diskriminasi dan hal ini mendorong pertumbuhan kota kewargaan (Polis). Sudah fitrah manusia, dalam kehidupan sehari-hari mereka mempunyai keinginan untuk bersatu satu sama lain dan bersatu dengan alam sekeliling, sehingga timbulnya kelompok sosial manusia. Dalam perspektif sosiologis, manusia yang berhubungan timbal balik itu disebut kelompok sosial yang masing-masing

\footnotetext{
${ }^{18}$ Amitai Etzioni, How to Built a Good Global Society (IPG 2/2004 pp.12-30) pp. 9-11, 200 -
} 205. 
menyadari keanggotaan kelompok, masing-masing menyadari keberadaan orang lain yang juga anggota kelompok dan masing-masing menyadari saling bergantung secara positif dalam mencapai tujuan bersama.

Bagaimana peran kesamaan fasilitas balai warga yang inklusiv dapat menjembatani adanya interaksi antara anggota RT/RW pemukiman dan RT/RW perumahan yang bertetangga langsung, sehingga dapat menghilangkan prasangka dan sterotype yang ada. Lewat pendidikan orang dewasa terkristalisasi dalam pikiran mereka lebih senang berinteraksi dengan tetangga yang homogen lebih tidak berisiko, yaitu lapisan atas sama lapisan atas, hidup exlusiv satu ras atau suku bangsa, sudah sulit untuk dikikis, karena sudah dianggap suatu life style yang biasa. Ditambah lagi dengan pemisahan secara fisik berupa dibangun tembok tembok berlin, maka akan bertambah prasangka-prasangka yang membelenggu orang dewasa . Tidak demikian halnya pada diri anak anak bebas dari prasangka. Dari sini kita dapat belajar banyak pada anak anak.

Upaya manusia dalam rangka memenuhi kebutuhan hidupnya dilaksanakan melalui proses sosial yang disebut interaksi sosial, interaksi sosial terjadi apabila ada kontak sosial antar individu atau kelompok yang dapat berupa kontak sosial bersifat primer, misalnya berjumpa, dan dapat sekunder misalnya berhubungan melalui media komunikasi , media sosial dan adanya komunikasi timbal balik diantara individu atau kelompok serta mempunyai maksud dan tujuan yang jelas. Berlangsungnya interaksi sosial didasarkan pada berbagai faktor antara lain faktor imitasi, sugesti, identifikasi dan simpati. Faktor-faktor tersebut dapat bergerak sendiri-sendiri atau secara terpisah maupun dalam keadaan bergabung.

Dalam setiap kelompok sosial selalu ada benih-benih pertentangan, namun setiap kali terjadi konflik dapat menjadi reda jika ada sikap toleransi dan interaksi sosial guna memelihara hubungan. Sebaliknya, jika benih pertentangan dibiarkan berkembang, maka keutuhan kelompok sosial akan pudar, sebab segala perasaan tidak puas semakin meluap dan disusul persaingan terbuka. Apabila kata persaingan diganti dengan perang, maka artinya masyarakat telah memprogramkan kekerasan atau perang terbuka, disini tidak ada rasa hormat lagi pada hukum, yang ada main hakim sendiri.

Secara umum konflik biasanya menghasilkan keseimbangan dan penyesuaian menyusul suatu perubahan. Hasil dari suatu konflik dapat berupa solidaritas bertambah, perubahan kepribadian atau sikap, akomodasi atau dominasi. Konflik secara umum 
dapat berupa konflik pribadi, konflik rasial dan kebudayaan, konflik antarkelas sosial, konflik politik dan pengaruh dan konflik internasional.

Akan tetapi terdapat juga prasangka sosial, stereotype dan stratifikasi sosial dalam masyarakat yang menyebabkan interaksi tidak berjalan lancar dan mengarah pada konflik. Apabila kelompok berkepentingan seperti developer untuk mendapatkan keinginan egoisnya dapat memicu atau menghembuskan konflik ini, agar orang mudah terpengaruh untuk membeli produknya, yang menjamin keamanan yang lebih (ganda)

Prasangka sosial: adalah sikap yang negativ yang diperlihatkan individu atau kelompok terhadap individu lain atau kelompok lain. Prasangka itu sebenarnya adalah salah sangka-missinformation, misscommunication dan miss intepretation-.sedangkan usaha untuk menghilangkan atau mengurangi prasangka tersebut dibedakan menjadi 2 macam, yaitu: Usaha Preventif yaitu usaha mencegah jangan sampai berprasangka dan usaha curative yaitu usaha menyembuhkan terhadap orang yang berprasangka

Prasangka timbul karena adanya perbedaan, di mana perbedaan ini menimbulkan perasaan superior, meliputi perbedaan fisik/biologis, ras; lingkungan/ geografis, misalnya: orang permukiman kompleks dan orang permukiman atau orang kota dan orang desa; harta benda, status sosial; kepercayaan/agama; norma sosial. Prasangka timbul karena kesan yang menyakitkan atau pengalaman yang tidak menyenangkan (misal kerusuhan di Bandung 1974 dan di Indonesia Mei 1998). Prasangka timbul karena adanya anggapan yang sudah menjadi pendapat umum atau kebiasaan di dalam lingkungan tertentu. Prasangka sosial tidak dibawa sejak dilahirkan tetapi terbentuk selama perkembangannya, baik melalui pendidikan maupun dengan cara identifikasi dengan orang-orang lain.

Oleh karena itu anak anak tidak mengenalnya dan telah dapat memberikan keteladanan kepada kita selaku orang dewasa. Kalau pendidikan orang perumahan tidak dibiasakan dengan inklusif, maka lambat laun ada tertanam dan mengendap dalam pikiran bawah sadar mereka suatu persepsi eksklusivitas. Apalagi hal hal eksklusivitas ini dipertajam dengan membuat batas batas berbentuk fisik seperti tembok berlin, pagar BRC dan pagar tembok rumah yang tinggi. Apalagi dalam=pendidikan dalam keluarga mereka sudah ditanamkan superioritas mereka terhadap kelompok lain. Maka konsep konsep egaliter yang merupakan semboyan Revolusi Perancis 1789 dan perang mempertahankan kemerdekaan kita 1945 - 1949 menjadi sirna. 
Dari hasil pengamatan penulis di Jerman dan di Indonesia disimpulkan orang dewasa harus banyak belajar dari ketauladanan anak-anak, dimana mereka tidak punya prasangka sosial. Dari observasi yang gamblang saja tampak bahwa di sekolah-sekolah internasional, JIS atau DIS (Deutsche Internationale School) tidak terdapat sedikitpun prasangka sosial pada anak-anak sekolah yang berasal dari bermacam-macam golongan ras atau kebudayaan. Mereka baru akan memperolehnya di dalam perkembangannya apabila mereka bergaul dengan orang dewasa erat dengan orang-orang yang berprasangka sosial. Dan hal ini berlangsung secara sendirinya dan pada taraf dunia bawah sadar melalui proses-proses imitasi, sugesti, identifikasi dan simpati yang memegang peranan utama di dalam interaksi itu. Sementara itu, secara tidak sadar mereka lambat laun mungkin memperoleh sikap-sikap tertentu terhadap golongangolongan tertentu yang lambat laun dapat melahirkan stereotype-stereotype terhadap tetangganya apalagi kalau mereka dipisahkan secara fisik oleh tembok berlin.

Selain itu, adapula satu faktor yang dapat mempertahankan adanya prasangka sosial seperti yang dapat berkembang secara tidak sadar itu, yaitu faktor ketidaksadaran (ketidakinsyafan) akan kerugian-kerugian masyarakat apabila prasangka itu dipupuk terus-menerus, yang mudah terjelma dalam tindakan-tindakan diskriminatif, apalagi terdapat kepentingan pihak ketiga (yaitu pihak developer yang ingin mengeruk keuntungan sebesar besarnya supaya customernya merasa terancam keamanannya dan diharapkan rajin membayar IPL, walau ia telah jual rumahnya). Kegiatan mengeksploitasi rasa ketakutan yang berlebihan ini saking elegannya tidak diraskan oleh customernya.

Beberapa upaya yang bisa dilakukan untuk mengatasi prasangka sosial diantaranya melalui rekayasa dalam hubungan antar kelompok, melalui sosialisasi dalam keluarga, sekolah, dan lingkungan, melalui rekayasa sosial, maupun melalui penyadaran diri pribadi. Menurut psikologi prasangka dipengaruhi juga oleh sejarah, politik, ekonomi, dan struktur sosial ${ }^{19}$, karenanya diperlukan pula adanya political will yang kuat dari pemerintah untuk melakukan upaya-upaya mengurangi prasangka misalnya dengan melakukan aksi tindak, intervensi dan bukan pembiaran dan bukan wacana wacana.

${ }^{19}$ Brown, 1995 
Mereka miskin karena sejarah diskriminasi penjajah yang cukup lama atau sistim liberalisme yang memberikan kesempatan kepada yang kaya. Berdasarkan kenyataan ini umumnya konstitusi dibanyak negara maju, selalu ada pasal yang melindungi pihak yang lemah (affirmativ action). Kalau pemerintah membiarkan (autopilot) dua kepentingan yang bersaing maka artinya ada keberpihakan pemerintah kepada yang kuat. Pemerintah baru dianggap netral bila ada keberpihakan kepada yang lemah. Pemerintah yang netral , bebas aktif, berdiri ditengah tengah atau tidak memihak dalam dua golongan yang bersaing dan sama kuat dibenarkan, pemerintah melakukan social engineering secara luas dan memaksa, di bidang politik, ekonomi, maupun social akan dapat memberikan kesejahteraan dan keadilan pada semua anggota masyarakat.

Ketakutan yang berlebihan, sikap pendirian yang tidak terkendali oleh akal (rasa ketakutan dan merasa tidak aman, sehingga baru merasa aman bila dibangun tembok berlin, padahal sudah ada Satpam, hansip dan pagar pagar tinggi) sengaja dibesar besarkan demi untuk kepentingan dalam bidang ekonomi Kepentingan lurah dan developer mengintimidasi dengan mendirikan tembok berlin agar warga desa menjual tanah mereka dengan harga murah dan pengembang menjual kembali dengan harga yang tinggi. Aksesibilitas jalan untuk menuju fasos-fasum fasilitas kesehatan, pendidikan, pasar bila ditutup akan mempertajam dan menimbulkan konflik hukum dan konflik laten. Peristiwa pembangunan tembok berlin yang mengepung dan mengisolir kampung mereka adanya bentuk interaksi sosial yang menyebabkan pertikaian (konflik) antar kelas sosial yang didasarkan pada perbedaan budaya , rasa ketakutan yang dihembuskan oleh developer dengan menjual rasa keamanan.

Upaya mediasi untuk menyelesaikan masalah secara damai melalui proses mediasi yang melibatkan pihak ketiga yaitu hakim mediator tidak akan membuahkan hasil, apabila tidak ada kewajiban atau keharusnya untuk menghadirkan pihak prinsipal yang bersengkata. Mengharuskan prinsipal hadir sendiri minimal 3 kali (bukan 1 x) pada waktu mediasi, dapat mengikis tunggakan perkara dan meningkatkan kualitas putusan.

UUD sebagai norma tertinggi dalam menciptakan masyarakat setara, telah diturunkan dalam UU No. 1 th 2011 vide ps. 112 ay 2 dimana benda milik publik , ruang publik seperti jalan umum dan jalan khususpun harus terbuka untuk umum, bukan milik eksklusiv warga tertentu. Pembeda-bedaan terhadap pemanfaatan barang milik 
publik, ruang publik, jalan umum dan perbedaan perlakuan pelayanan publik terhadap masyarakat pemukiman dan masyarakat perumahan bertentangan dengan tujuan kemerdekaan kita dan pada gilirannya kita kembali ke jaman VOC dimana pengusaha yang berkuasa, yang punya kepentingan sendiri, berbeda dengan kepentingan rakyat banyak. Kerajaan Romawi yang hukumnya banyak bersifat indivudualistis, telah menerima pranata hak servitut, dan telah diterima sebagai fenomena universal. Karena bumi dan air milik Allah dan pemerintah dalam mendistribusikan harus adil, kepada perorangan dan badan hukum, termasuk akses jalan umum atau jalan khusus serta hak servitut untuk mencapai milik masing masing. Jangan sampai terdapat diskriminasi, dimana orang untuk mendapat $21 \mathrm{~m} 2$ tanah saja susah bukan main, tetapi dilain pihak untuk satu grup perusahaan diberikan pemerintah 2 juta ha, atau satu perusahaan diberikan ijin lokasi untuk 6000 ha, sedangkan untuk pengembang yang lain untuk dapat ijin lokasi 2000 ha, 200 ha atau 2 ha saja susah.

Di tahun 2006 dari hasil wawancara dengan kepala Biro Hukum Kementerian Perumahan Rakyat, dapat dicatat bahwa Pemerintah tidak dalam posisi memberikan ijin cluster untuk perumahan. Sejalan dengan maraknya cluster lalu pemkot Bekasi mengeluarkan ijin cluster, tetapi tahun 2013 banyak cluster dijadikan kedok pelanggaran RTH dibawah 30\%, maka pemkot Bekasi 2013 memperketat ijin cluster untuk perumahan. Tindakan ini sangat tepat, karena di banyak negara cluster untuk perumahan dilarang, akan tetapi cluster untuk industri difasilitasi. Ia bertentangan dengan prinsip kesetaraan dengan perumahan non cluster, karena jalan, RTH sebagai benda publik tidak boleh dinikmati secara ekklusiv. Kecuali mereka yang super kaya, diadakan pengecualian, karena mereka bayar pajak penghasilan yang besar dan bahkan pajak jalan khusus ia bayar, karena sifat exclusiv pemakaian jalan tersebut. Kasus di Serpong mencuat karena developer merubah sistim terbuka menjadi sistim cluster berimbas pada tetangga. Ditambah lagi perubahan peruntukan lahan dari perumahan menjadi komersial mix used (asssembling Handphone) dan dalam pemberian IMB Smart Telecom tidak mengacu kepada IMB tetangga yang telah lebih dahulu mempunyai $\mathrm{IMB}^{20}$. Perumahan cluster bertentangan dengan pendidikan kewargaan, kesetaraan dan multi kulturalisme. Secara sosiologis sulit untuk dikembangkan, karena

\footnotetext{
${ }^{20}$ Lihat putusan MA RI No. 3409 K/Pdt/2012 diputus tanggal 27.8.2014 jo Putusan Pengadilan Negeri No. 191/Pdt.G/2009.
} 
akan memicu ketegangan sosial dan rentan untuk dijadikan kamping hitam. Karena keamanan yang hakiki bukannya menambah tinggi tembok dan pagar, melainkan interaksi dan menghilangkan prasangka prasangka yang tidak sehat . Kalau kran ijinnya dibuka, harus sangat selektif untuk daerah yang sama sekali baru dan renggang penduduknya dan besar kavelingnya minimal $800 \mathrm{~m} 2$ dan jalan khusus harus bayar pajak kepada pemerintah. Sistim rumah induk dan diapit 3 atau 6 rumah sederhana punya akan sejarah untuk dikembangkan. Demikian pula sistim cohousing sangat tepat untuk global community ${ }^{21}$ dan sistim tiga generasi. Ini sejalan dengan konsep rumah panjang di Kalimantan atau Rumah Gadang di Sumbar. Bagi daerah yang sudah ada masyarakatnya, cocok dibuat sistim co-housing (Rumah bersama) ala Swedia dan diadopsi oleh $\mathrm{USA}^{22}$, dimana satu dan lain fasos dan fasum terintegratif dan warga saling menyesuaikan diri dan saling berinteraksi.

Peranan aktiv Pemerintah Kota sangat diharapkan dalam pemerataan fasosfasum dan mendorong masyarakat inklusiv dan mengetatkan system masyarakat eksklusiv (cluster) , karena secara yuridis, filosofis dan sosiologis sulit untuk dapat dipertanggung jawabkan. Kalau orang dewasa tidak mau belajar dari anak anaknya, maka upaya lain untuk mengurangi prasangka etnik nyaris identik dengan upaya menumbuhkan pemahaman lintas budaya dan menumbuhkan energi positif dalam diri individu. Pemahaman lintas budaya terkandung pemahaman akan keberagaman dan penghargaan akan perbedaan, serta perilaku sikap dan tindak dalam situasi multietnikmultikultur. Salah satu bentuk nyata dari terbangunnya pemahaman lintas budaya dalam masyarakat adalah terbangunnya komunikasi antar kelompok yang efektif. Menurut Liliweri (2005) dalam masyarakat majemuk, efektivitas komunikasi antar etnik sangat ditentukan oleh mutu efektivitas komunikasi intraetnik. Diperlukan upaya memelihara suasana kemajemukan melalui a. Efektivitas komunikasi antara intraetnik dengan antaretnik, b.Memandang ciri dan sifat khas yang positif antara intraetnik dengan antaretnik, c.

\footnotetext{
${ }^{21}$ Lihat Murundaka Cohousing, Australia.

${ }^{22}$ McCamant dan Durrett , Cohousing: A Contemporary Approach to Housing Ourselves, 2003
} hal. 158. 
Memilih dan memelihara keseimbangan dalam pelbagai bentuk interaksi sosial intraetnik dengan antar etnik dan d. Bertindak secara adil dalam tindakan diskriminasi anggota intraetnik dengan antaretnik.

Upaya meminimalisir prasangka sosial dengan meningkatkan intensitas komunikasi antar etnik itu sendiri. Misalnya melalui Hubungan Antar Kelompok sehingga prasangka dan stereotip negatif akan semakin berkurang; Melalui Sosialisasi upaya sosialisasi nilai-nilai egalitarian dan tidak berprasangka mulai dari rumah atau keluarga, di sekolah maupun dimasyarakat; Melalui Rekayasa Sosial.

Prasangka etnik juga disebabkan oleh faktor sejarah, ekonomi, politik, budaya, dan struktur sosial ${ }^{23}$. Karenanya diperlukan adanya political will yang kuat dari pemerintah untuk melakukan upaya-upaya mengurangi prasangka. Pemerintah mempunyai kemampuan social engineering secara luas dan berkelanjutan; Melalui Penyadaran Diri dengan cara mengakui bahwa kita berprasangka dan bertekad untuk menguranginya dan respek akan perbedaan yang ada. Dari sini kearifan lokal yang ada dalam hukum bertetangga pada Kesatuan Masyarakat Hukum Adat harus ditumbuhkembangkan lagi, sebagaimana masyarakat Murundaka bentukan cohousing merumuskan visi komunalnya, visi kekeluargaan.

\section{Penutup}

\section{Kesimpulan}

a. Kedudukan hak servitut tidak dapat tergoyahkan dalam yurisprudensi tetap Indonesia diuntungkan dengan pembangunan banyak rumah susun dan konsolidasi tanah masuk dalam UU perumahan tahun 1992 dan didahului oleh Peraturan Kepala BPN RI No. th 1991 sehingga sangat membutuhkan hukum bertetangga dan jalan (umum, khusus, servitut)

b. Banyak kepentingan yang bermain dalam mewujudkan program pemerintah membangun tanpa menggusur. Bahan sosialisasi konsolidasi tanah di banyak Kantah yang ditemui telah menjadi bahan tidak berguna, karena ditumpuk dan sebagian masih dalam karton . Bahkan pegawai Kantahpun banyak yang tidak tahu konsolitasi tanah. Hal ini jelas bila konsolidasi tanah jalan, maka developer akan kesulitan memperoleh tanah dengan harga murah, karena tanah yang sudah lewat konsolidasi tanah menjadi

\footnotetext{
${ }^{23}$ Brown 1995
} 
tanah terdaftar (bersertipikat) dan harganya naik, sehingga developer tidak mau meliriknya. Kalau developer tidak belanja maka Lurah dan sekdes serta PPAT sementara tidak mendapat penghasilan tambahan, karena sedikit transaksi yang berjalan. Maka konsolidasi tanah programnya sengaja ditutup tutupi dan sosialiasi tidak pernah berjalan dengan alasan tidak ada dana dan Walikota/Bupati dan Kantah merasa lebih banyak masuk uang dari pada proyek pengadaan lahan dengan cara pembebasan tanah untuk kepentingan umum, ketimbang lewat konsolidasi tanah. Perhatian pemerintah sangat kurang pada konsolidasi tanah, karena tidak ada insentifnya (reward) dan tolak ukurnya yang jelas bila tidak capai target (punishment).

c. Pemerintah harus mulai persiapan konsolitasi tanah secara benar tanpa ada titipan dari pemodal dan/atau developer. Disini leadership dari Kepala Daerah diuji apakah dipatuhi dan diikuti oleh anggota konsolidasi tanah. Konsolidasi tanah ini belum fokus pada wilayah yang tingkat kepadatan penduduknya rendah, untuk membuka daerah baru lebih efisien dari pada membongkar dan membangun lagi, hanya perlu pematangan tanah untuk jadi kaveling siap bangun.

\section{Saran}

a. Perlu sosialisasi hak servitut lewat radio dan program Kanwil Hukum dan HAM provinsi masing masing, agar mengurangi sengketa orang bertetangga, yang pada akhirnya menjadi umpan developer untuk dibeli dengan harga murah, karena tanah sengketa atau hubungan bertetangga sudah tidak harmonis lagi.

b. Pemerintah harus memberikan target kepada Bupati/Walikota dan Kantah setempat, misalnya konsolidasi tanah harus mencakup luas 1/3 dari ijin lokasi yang diberikan dalam wilayahnya, akan tetapi objek konsolidasi tanah harus diluar ijin lokasi yang ada. Bila target pemerataan kepemilikan tercapai harus diberikan reward berupa di promosikan pada jenjang yang lebih tinggi. Bila gagal dicopot jabatannya dan masuk staf. Dengan demikian membangun dengan konsolidasi tanah memberikan pendidikan kepada warga menjadi masyarakat kewargaan yang paham akan hak dan kewajibannya sebagai warga negara.

c. Pemerintah harus mulai serius dan sadar melaksanakan konsolidasi tanah, dimana konsolidasi tanah yang baik akan menunjang hak servitut dan dapat meningkatkan status tanah hak servitut menjadi jalan umum dan perlu desain 
konsolidasi tanah yang benar tanpa titipan dan KKN agar peta rincikan awal dan peta pengembalian awal sinkron dengan advis planning dan sebaiknya pemerintah tidak mengharapkan tanah sumbangan yang direlakan terlalu besar, bila perlu $20 \%$ dari luas ukuran awal, maka sebaiknya separo dari $20 \%$ yang merupakan sumbangan dan separo lagi dengan ganti untung, sehingga warga dapat memilih konsolidasi tanah sukarela. Luas cakupan objek konsolidasi hendaknya jangan ditentukan, tapi tergantung harga tanah. Kalau harga tanah sudah mahal, maka 6 KK dengan tanah seluas 3000 meter sudah dapat dilakukan konsolidasi tanah baik sukarela ataupun kedinasan. Bank Tanah atau perusahaan tanah milik negara seperti di Malaysia dapat diteliti agar harga tanah tidak melambung. Pemerintah harus sadar dan bersaing dengan swasta untuk mendistribusikan tanah kepada rakyat secara adil dan seluas mungkin jangkauannya. 


\section{Daftar Pustaka}

Amitai Etzioni, How to Built a Good Global Society (IPG 2/2004)

Erhard Eppler, Auslaufmodel Staat? Frankfurt a.M; Suhrkamp Verl. 2005, Jakarta FES 2010 (terj) Bab 5 : batas batas Swastanisasi.

BRD, Facts About Germany. Frankfurt am Main , 2005, Societaet Verlag

Irwanto. Psikologi Umum. Jakarta, 2002, Prenhallindo.

Johnson, G. Allan. Human Arrangements \& Introduction to Sociology. Harcourt Brace. Inc. Sandiego1986.

Jasmin Lebeda, Die Möglichkeiten zur Bewertung der Servituten Leitungs-, Wege- und Fensterrecht im Rahmen der Verkehrswertermittlung, Wien 2009

Alo Liliweri, Prasangka dan Konflik. Yogyakarta, 2002, PT LKiS Pelangi Aksara

Marimin Tri Pranoto dkk. Sosiologi. Bandung, 2005. CV Regina

Moeliono, Anton.M. Kamus Besar Bahasa Indonesia. Jakarta, 1988

Mulyana, Rakhmat Jalaluddin. Komunikasi Antar Budaya. Bandung, 1990. Risda Karya

Raquel Polnik, right to adequate housing . UN Rapporteur for Housing

Andi Rahardiansah, Trubus dan Endar Pulungan. Pengantar Sosiologi Hukum. Jakarta. 2008.Universitas Trisakti.

Resolution 21/10 : Strengthening the Habitat and Human Settlement Foundation : experimental financial menchanism for pro-poor housing and infrastructure.

Soerjono Soekanto. Sosiologi Suatu Pengantar. Jakarta, Rajawali Pers, 1990.

Soetandyo Wignjosoebroto, Hukum, Paradigma, Metode dan Dinamika Masalahnya. Jakarta, $2002 \quad$ Elsam-Huma.

UN Habitat, Affordable Housing 